\title{
Insights into the genetic foundation of aggression in Papio and the evolution of two length-polymorphisms in the promoter regions of serotonin-related genes (5-HTTLPR and MAOALPR) in Papionini
}

Urs Kalbitzer ${ }^{1,2^{*}}$, Christian Roos ${ }^{3}$, Gisela H. Kopp ${ }^{1,4,5}$, Thomas M. Butynski ${ }^{6}$, Sascha Knauf ${ }^{7}$, Dietmar Zinner ${ }^{1}$ and Julia Fischer ${ }^{1}$

\begin{abstract}
Background: Aggressive behaviors are an integral part of competitive interactions. There is considerable variation in aggressiveness among individuals both within and among species. Aggressiveness is a quantitative trait that is highly heritable. In modern humans and macaques (Macaca spp.), variation in aggressiveness among individuals is associated with polymorphisms in the serotonergic (5-HT) neurotransmitter system. To further investigate the genetics underlying interspecific variation in aggressiveness, 123 wild individuals from five baboon species (Papio papio, P. hamadryas, P. anubis, P. cynocephalus, and P. ursinus) were screened for two polymorphisms in promoter regions of genes relevant for the 5-HT system (5-HTTLPR and MAOALPR).

Results: Surprisingly, despite considerable interspecific variation in aggressiveness, baboons are monomorphic in 5-HTTLPR, except for P. hamadryas, which carries one additional allele. Accordingly, this locus cannot be linked to behavioral variation among species. A comparison among 19 papionin species, including nine species of macaques, shows that the most common baboon allele is similar to the one described for Barbary macaques (Macaca sylvanus), probably representing the ancestral allele in this tribe. It should be noted that (almost) all baboons live in Africa, but within Macaca only M. sylvanus lives on this continent. Baboons are, however, highly polymorphic in the so-called 'warrior gene' MAOALPR, carrying three alleles. Due to considerable variation in allele frequencies among populations of the same species, this genotype cannot be invoked to explain variation in aggressiveness at the species level.

Conclusions: This study provides another indication that 5-HTTLPR is not related to aggressiveness in primates per se, but may have been under differential selective pressures among taxa and potentially among populations in different geographic regions. The results on MAOALPR alleles in Papio indicate that variation in the metabolism of monoamine neurotransmitters and associated behaviors is more important among populations than among species. We, therefore, propose to compile behavioral data from additional populations of Papio to obtain further insight into the genetics underlying behavioral differences among primate species.
\end{abstract}

Keywords: 5-HT, Behavioral genetics, Candidate gene, Primate, MAOA-uVNTR, Neurotransmitter, Baboon, Macaque, Macaca

\footnotetext{
* Correspondence: urs.kalbitzer@ucalgary.ca

${ }^{1}$ Cognitive Ethology Laboratory, German Primate Center (DPZ), Leibniz Institute for Primate Research, Kellnerweg 4, 37077 Göttingen, Germany

${ }^{2}$ Department of Anthropology and Archaeology, University of Calgary,

2500 University Dr NW, Calgary, AB T2N 1N4, Canada

Full list of author information is available at the end of the article
} 


\section{Background}

\section{Genetics of aggression}

In order to maximize their fitness, individuals compete for resources, including mates. In this context, aggressive behaviors, which are commonly defined as physical attacks and the threat of such attacks [1] play a key role. Escalated aggression, however, may incur high costs such as fatal injury. According to Anholt and Mackay [2], intermediate levels of aggressiveness should, therefore, be favored. As such, aggressiveness is assumed to be under stabilizing selection [2]. Nevertheless, variation in aggression can be observed on different levels. In addition to short-term variation within individuals (e.g. in relation to context), there are relatively stable long-term differences among individuals (i.e. personality differences, e.g. [3]) and among closely related species (e.g. [4-6]).

Within many species, including modern humans (Homo sapiens) [3] and non-human primates [7], heritability estimates for inter-individual differences in aggressiveness are generally high [2]. The strong genetic component has been demonstrated by experiments in which highly aggressive or docile individuals have been bred within a few generations, for example in house mouse (Mus musculus) [8] or in silver fox (Vulpes vulpes) [9]. Aggressiveness constitutes a quantitative trait affected by multiple genes, but the specific combination of genes involved in aggressiveness is not clear [2].

Several hormone and neurotransmitter systems are assumed to affect aggressiveness. If so, corresponding genes may be involved in the regulation of associated behaviors $[10,11]$. One neurotransmitter system associated with aggressiveness and impulsiveness in mammals is the brain serotonin (5-HT) system (reviewed in [12, 13]). Research on rhesus macaques (Macaca mulatta) indicates that individual differences in 5-HT activity are heritable $[14,15]$ and stable over time [16-18]. This makes the 5-HT system a good candidate to be associated with genetic-based stable differences in aggressiveness among individuals or species.

The 5-HT transporter (5-HTT) and monoamine oxidase A (MAOA) are two important proteins regulating the 5HT system. 5-HTT is responsible for the re-uptake of 5-HT from the synaptic cleft, while MAOA oxidizes 5-HT to its metabolite 5-hydroxyindoleacetic acid (5-HIAA). Accordingly, variants of genes encoding for these proteins may affect variation in aggressiveness. Regulatory regions (i.e. promoters) are of particular interest as they determine the transcription profile of a gene [19]. While mutations in coding regions can affect the functionality of a gene product, including inactivation, mutations in promoter regions may only affect transcriptional activity. Hence, promoter regions appear to be especially suitable targets for natural selection acting on quantitative traits [19], such as aggressiveness.

For the 5-HTT gene (SLC6A4), a functional lengthpolymorphism in the promoter region, the 5-HTT-linked polymorphic region $(5-H T T L P R)$ is well documented in humans [20], as well as in several species of apes and Old World monkeys [21-23]. Variation in length is caused by a variable number of 21-23 base pairs (bp)-repeat elements. Hominoids (humans and apes) vary at polymorphic locus 1 (PL1), though there is some variation among hominoid species for the specific position of this locus [23]. Macaques (Macaca spp.), in contrast, vary at polymorphic locus 2 (PL2) [21]. The 5-HTTLPR genotype appears to affect the in-vitro transcription rate (humans [20]; M. mulatta [24]), and various behaviors (humans e.g. [25, 26]; M. mulatta e.g. [27, 28]). As aggression is thought to be linked to 5-HT activity, the effect of the 5-HTTLPR genotype on aggressiveness has been investigated (e.g. [28]). The results, however, are inconsistent, and recent meta-analyses did not resolve the involvement of this polymorphism in aggressiveness $[29,30]$.

In the same context, the effects of variants of the $M A O A$ gene have been intensively studied. Brunner et al. [31] reported on a Dutch family carrying a nonsense mutation in the $M A O A$ gene that resulted in an extremely aggressive phenotype in males [31]. Importantly, the gene is located on the X-chromosome; males only possess one copy whose disruption leads to a complete inactivation of MAOA. The behavioral consequences of this disruption were confirmed by 'knock-out' experiments in mice which resulted in a similar increase in male aggressiveness [32-34]. These observations indicate the importance of the $M A O A$ gene for the regulation of aggression, but genetic variants must be more common than such rare (and disruptive) non-sense mutations in order to be linked to common variation in behavior.

The MAOALPR (or MAOA-uVNTR) represents such a common and important polymorphism in primates [35-37]. Similar to 5-HTTLPR, this polymorphism consists of a variable number of repeats within the promoter region of the $M A O A$ gene. The consensus sequence varies among species (18-30 bp), and the number of repeats differs both among and within many species [37-39]. In humans [35] and in M. mulatta [36], different alleles result in different in-vitro transcription rates and appear to have an impact on aggressiveness and impulsiveness (humans [40]; M. mulatta [36, 41]; review [42]; meta-analyses $[29,30])$. These observations gave rise to the nickname 'warrior gene' for the $M A O A$ gene (e.g. [43]).

\section{Interspecific behavioral variation in macaques in relation to 5-HTTLPR and MAOALPR genotypes}

At the individual level, the effects of 5-HTTLPR and $M A O A L P R$ genotypes on aggressiveness do not appear to be simple additive genetic effects. Instead, both 5HTTLPR [28] and MAOALPR [36, 40] affect variation in aggressiveness depending on early experiences [i.e. genetic $\mathrm{x}$ environment interaction $(\mathrm{G} \times \mathrm{E})]$. At the species 
level, in contrast, variation in aggressiveness may be more generally linked to different genotypes at these loci. This has been suggested for different species of macaques, which vary in their degree of tolerance [6], possibly related to the distribution of different alleles in 5-HTTLPR and MAOALPR [38, 44, 45]. It should be noted that (1) most samples used in these studies came from captive individuals [38], whose genetic composition may not reflect a natural population, and (2) that sample sizes ranged from two to several hundred individuals per species.

\section{Interspecific behavioral variation among baboons}

Baboons (Papio spp.) are well suited to further investigate the genetic differences underlying variation in aggressiveness because the species, although closely related, show considerable variation in social behavior. Furthermore, they are closely related to macaques (both belong to the tribe Papionini) and, therefore, likely to show similar polymorphisms.
Papio is thought to have originated in southern Africa, and started to disperse across Africa around 2 million years ago (mya) [46]. At present, baboons inhabit large parts of sub-Saharan Africa and a small part of Arabia (Fig. 1). Commonly, Papio is divided into six morphotypes [46], which should be classified as species according to the phylogenetic species concept - although they commonly hybridize in contact zones (e.g. [47-49]). In accordance with recent literature [50] we recognize the morphotypes as species.

Behavioral observations suggest that baboons show a gradient of decreasing male aggressiveness and increasing male tolerance from southern to northern species $[5,51,52]$. In southern African chacma baboons (P. ursinus) and in the more northern yellow baboons ( $P$. cynocephalus) and olive baboons (P. anubis), males show intense contest competition over mates [53-55], and fights often lead to serious injuries [56-58]. Yellow and olive baboon males appear to show a higher spatial tolerance, potentially linked to the

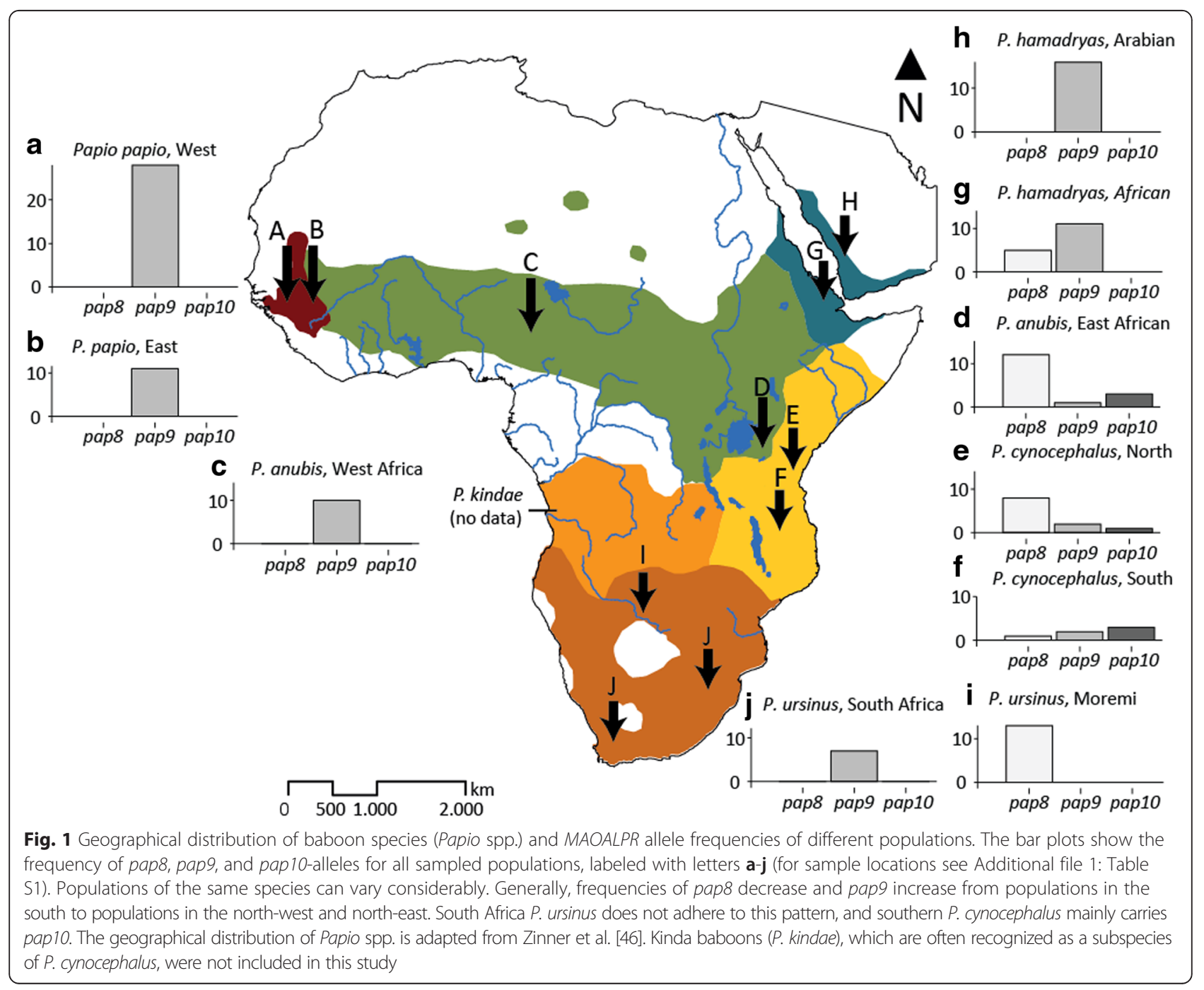


occurrence of coalitions in these two species (e.g. [59, 60]). In hamadryas baboons ( $P$. hamadryas) of north-eastern Africa, fights among males are highly ritualized and rarely result in injuries [61]. Males not associated with females show a high spatial tolerance but once they associate with females they become less tolerant [61, 62]. Finally, male Guinea baboons ( $P$. papio) of north-western Africa, show high tolerance, as well as low frequency and intensity of fights [5, 63-65].

Females of different baboon species also vary with regard to their social behavior. Females of $P$. ursinus, $P$. cynocephalus and $P$. anubis show highly despotic social relationships [66-68], while female behavior in P. hamadryas and $P$. papio is mainly male-directed and females rarely interact with each other ( $P$. hamadryas [61], but see [69]; P. papio [70]; UK pers. obs.), which includes the absence of frequent aggressive interactions among females. Thus, variation in female behavior is largely in line with the gradient seen in males but less pronounced. Baboons, therefore, represent a promising model to further investigate the genetic foundation of variation in aggressiveness in primates.

\section{Aims of this study}

We investigated the 5-HTTLPR and MAOALPR genotypes in baboons to test whether interspecific differences in allele frequencies correlate with variation in aggressiveness. It appears that baboon species vary quantitatively rather than qualitatively in behavior. We, therefore, predicted that different baboon species carry the same alleles but in different frequencies (Prediction 1), and that P. papio and $P$. ursinus are the most distinct species as concerns their genotypes (Prediction 2), as they seem to represent opposite extremes in aggressive behavior [5]. Comparable data on aggressiveness are only available for a few populations of each species. Also, it is unknown whether some geographically close populations of different species exhibit more similar levels of aggressiveness. We, therefore, included samples from different populations of each species to investigate whether allele frequencies change gradually from southern populations to northern populations, or discretely among species. Because comparable behavioral data are not available for most of these populations, we made no specific prediction as to whether this change is gradual or discrete.

Finally, we compared the 5-HTTLPR and MAOALPR genotypes of baboons with those of other papionin species to obtain further insights into evolutionary changes within these well-known promoter polymorphisms over the last 8 million years among papionin species and geographic regions. To do so, we used published sequence information from other species and, in the case of 5HTTLPR, we analyzed additional samples from other papionin species. Because species of this tribe are relatively closely related (Macaca split from other papionin species only about 8 mya [71]), we expected to find similar alleles in all papionin species (Prediction 3). More specifically, for 5-HTTLPR, we expected to find variation at the PL2, whereas for MAOALPR, we expected to observe alleles previously found in Macaca and Theropithecus, with 5, 6, and 7 copies of the $18 \mathrm{bp}$ repeat $[37,38]$.

\section{Methods \\ Ethical statement}

Blood samples from zoos in Germany were taken during routine health checks by experienced veterinarians. Blood samples from $P$. anubis in Tanzania were obtained from a study of disease in $P$. anubis [72]. Tissue samples from $P$. papio in Senegal were obtained from a previous study on social behavior and relatedness in P. papio [64]. Blood samples from $P$. hamadryas in Saudi Arabia were obtained from a previous study on the evolution of $P$. hamadryas [73]. No blood or tissue samples were collected specifically for this study. Fecal samples were collected non-invasively. All research complied with protocols approved by the Animal Welfare Body of the German Primate Center (Deutsches Primatenzentrum, DPZ) in Germany, and adhered to the legal requirements of the countries from which samples were obtained. The study was carried out in compliance with the principles of the American Society of Primatologists for the ethical treatment of non-human primates (https:/www.asp.org/society/ resolutions/EthicalTreatmentOfNonHumanPrimates.cfm). No animals were sacrificed or harmed for this study.

\section{Animals}

Five species of baboons were analyzed for variation in 5HTTLPR and MAOALPR. In total, 123 wild baboons from five species were screened, including two populations of each species (Additional file 1: Table S1). We analyzed 31 samples from $P$. papio (15 females, 16 males), including 23 samples from the western (Senegal and western Guinea) and eight samples from the eastern part of the species' distribution (eastern Guinea and Boucle du Baoulé National Park, Mali [74]); 32 samples from $P$. hamadryas (11 females, 21 males), comprising 20 African (Eritrea and Ethiopia), and 12 Arabian samples (Saudi Arabia); 21 samples from $P$. anubis (8 females, 13 males), including 10 East African (Lake Manyara National Park in Tanzania) [72] and 11 West African samples (Gashaka-Gumti National Park in Nigeria); 21 samples from $P$. cynocephalus (8 females, 13 males), all samples from Tanzania [75], including nine samples from individuals belonging to the northern mitochondrial (mt) clade and 12 samples from individuals of the southern mt clade; 18 samples from $P$. ursinus (3 females, 15 males), including 13 northern $P$. ursinus from Botswana 
(Moremi Game Reserve), and five southern P. ursinus from the Cape region and around Drakensberg, RSA.

Samples included blood, tissue, and feces. Genotypes of all samples were determined for 5-HTTLPR, while $M A O A L P R$ was assessed for 98 samples (see below). Additionally, samples were analyzed for 5-HTTLPR from one mandrill (Mandrillus sphinx), one drill (Mandrillus leucophaeus), one golden-bellied mangabey (Cercocebus chrysogaster), and one black mangabey (Lophocebus aterrimus) originating from zoos in Germany.

\section{Genotyping}

All samples not provided as DNA were extracted from feces and tissue using the Gen-ial all-tissue DNA-kit (GEN-IAL, Troisdorf, Germany) following the standard protocol with some modifications: (1) $10 \mu \mathrm{L}$ of $1 \mathrm{M} \mathrm{DTT}$ were added before the first incubation; (2) samples were incubated on a thermo block at $65^{\circ} \mathrm{C} / 600 \mathrm{rpm}$ for $60 \mathrm{~min}$ followed by overnight incubation at $37{ }^{\circ} \mathrm{C} / 300 \mathrm{rpm}$; and (3) on the day after the first centrifugation step, a maximum of $1000 \mu \mathrm{L}$ of the supernatant was transferred into a new tube and $80 \%$ vol. chloroform was added, briefly mixed by hand, centrifuged for $10 \mathrm{~min}$ at 13,000 rpm, and the upper phase was transferred into a new tube to which $75 \%$ vol. of Lyse 3 was added.

In a first step for 5-HTTLPR genotyping, high-quality (i.e. tissue or blood) samples were amplified using primers that amplified this locus in other Papionini (stpr5, 5'-GGC GTTGCCGCTCTGAATGC-3'; stpr3, 5'-GAGGGACTGAGCTGGACAACCAC-3'; amplicon size 700 bp) [21]. After obtaining sequences for baboons, new primers were designed using AmplifX ver. 1.6.3 [76]. These primers (p5-HTTLPRf, 5'-CTCTGAATGCCAGCACCT AACC-3'; p5-HTTLPRr, 5'-AGGGGAGATAATGAGG GTGCAA-3') amplify shorter fragments of 255/277 bp, including the entire PL2. This enabled the genotyping of low-quality DNA samples (i.e. feces).

For MAOALPR genotyping, primers described for other Papionini were used $(M A O A$-jrwF2, 5'-AGAAGGGCT GCGGGAAGC-3'; MAOA-jrwR, 5'-GTGCTCCACTGGGAACTGG-3'; amplicon sizes 423/441/459 bp in baboons) [37], and then primers amplifying shorter fragments of 377/ 395/413 bp in baboons were designed (pMAOALPRf, $5^{\prime}$ GGCTGCGGGAAGCAGAACA-3'; pMAOALPRr, 5'-CC ACTCAGAACGGATGCTCCATT-3'). Due to the length and characteristics (i.e. very similar repeats) of this repeat region, designing primers that amplify shorter fragments was not possible. This explains the drop-out of several samples for this locus; the amplification of nuclear DNA fragments of $400 \mathrm{bp}$ from fecal DNA was sometimes not achievable, most likely due to degradation [77].

All PCR reactions were conducted in a $30 \mu \mathrm{L}$ PCR-mix (1x reaction buffer, $0.16 \mathrm{mM}$ for each $\mathrm{dNTP}, 0.33 \mu \mathrm{M}$ for each primer, 1 U BiothermTaq 5000 [Genecraft, Germany], and $0.6 \mathrm{mg} / \mathrm{ml} \mathrm{BSA}$ ). We used $~ 50 \mathrm{ng}$ of DNA per reaction for tissue and blood samples. As the determination of target-species-DNA concentration in extracts from fecal samples is very labor-intensive [78], we started with $1 \mu \mathrm{L}$ of extract and increased incrementally to $2 \mu \mathrm{L}$ and $4 \mu \mathrm{L}$ (in case the initial amplification was not successful).

The thermo cycler setting for stpr-primers included (1) an initial denaturation step at $94{ }^{\circ} \mathrm{C}$ for 2 min followed by (2) 35 cycles of $94{ }^{\circ} \mathrm{C}-60{ }^{\circ} \mathrm{C}-72{ }^{\circ} \mathrm{C}$, each step for $60 \mathrm{~s}$. and (3) a final elongation at $72{ }^{\circ} \mathrm{C}$ for $5 \mathrm{~min}$. For p5HTTLPR-primer, (1) the initial denaturation step was at $94{ }^{\circ} \mathrm{C}$ for 2 min followed by (2) 35-45 cycles (depending on sample quality) of $94{ }^{\circ} \mathrm{C}-62{ }^{\circ} \mathrm{C}-72{ }^{\circ} \mathrm{C}$, each step for $30 \mathrm{~s}$, and (3) a final elongation at $72{ }^{\circ} \mathrm{C}$ for $5 \mathrm{~min}$. For jrwprimers, (1) the initial denaturation step at $94{ }^{\circ} \mathrm{C}$ for $2 \mathrm{~min}$ was followed by (2) 35 cycles of $94{ }^{\circ} \mathrm{C}-65^{\circ} \mathrm{C}-72{ }^{\circ} \mathrm{C}$, each step $60 \mathrm{~s}$, followed by (3) a final elongation at $72{ }^{\circ} \mathrm{C}$ for 5 min. For pMAOALPR-primers, (1) an initial denaturation step at $94{ }^{\circ} \mathrm{C}$ for 2 min was followed by (2) $40-50$ cycles of $94{ }^{\circ} \mathrm{C}-70{ }^{\circ} \mathrm{C}-72{ }^{\circ} \mathrm{C}$, each step $60 \mathrm{~s}$, followed by (3) a final elongation at $72{ }^{\circ} \mathrm{C}$ for $5 \mathrm{~min}$.

To obtain sequences, PCR products were excised from 1.0-2.5 \% agarose gels, purified with the Qiagen Gel Extraction Kit (Qiagen, Germany), and sequenced on an ABI3130xL sequencer using the BigDye Terminator Cycle Sequencing Kit (Applied Biosystems, Germany). Sequences were manually checked, edited, and aligned in Bioedit ver. 7.2.3 [79]. To compare loci among species, and to identify core sequences and number of tandem repeats, we used Tandem Repeats Finder ver. 4.07b [80].

Each allele was sequenced at least once for each species. The genotypes of the remaining (non-sequenced) samples were determined by comparing the size of PCR products with fragments of known length on 2-3 \% agarose gels - as commonly done in previous studies (e.g. [38]). Genotyping was repeated once for 5-HTTLPR as most baboon species were monomorphic; only samples from (polymorphic) African P. hamadryas were genotyped three times to avoid allelic dropout [81]. Similarly, for MAOALPR, each allele was sequenced at least once per species. The remaining (non-sequenced) samples were genotyped by length comparisons of PCR products on agarose gels. All samples (sequenced- and nonsequenced) were genotyped three times. As males possess only one copy of the X-chromosomal MAOA gene, only allele frequencies (instead of genotype frequencies) are reported here for both loci (for all genotypes, see Additional file 1: Table S1). For samples derived from individuals of unknown sex, we determined the sex by a gonosomal PCR-based sexing method (C. Roos, unpublished). Sex determination was repeated once for each of these samples. 
We used Cochran-Mantel-Haenszel Tests (function mantelhaen.test in $\mathrm{R}$ ver. 3.1.2; [82]) to detect differences in allele frequencies among species, using populations as different strata. This test indicates whether species generally differ in allele frequencies. The same test was used to conduct post-hoc comparisons between species, and Bonferroni corrected the alpha value to 0.005 as 10 species comparisons were calculated. To avoid false conclusions based upon varying number of samples from different populations, the number of alleles in the population with the larger sample size was reduced to the number of alleles in the population with smaller sample size. The original proportion of specific alleles was retained by calculating: total number of alleles in smaller population $\mathrm{x}$ number alleles $\mathrm{A}$ in larger population/total number of alleles in larger population.

\section{Results}

\section{5-HTTLPR}

The 5-HTTLPR genotype in baboons consists of multiple repeats with the core sequence $5^{\prime}$-CTGCACCCCTCC CAGCATCTCCC-3'. There is, however, considerable variation among consecutive repeats (Additional file 2: Figure $\mathrm{S} 1)$. There is a short allele (papS) with 24.2 repeats, and a long allele ( $p a p L)$ with one additional repeat in the PL2-4 (Fig. 2). The sequence of this additional repeat is identical to the adjacent repeat (at PL2-3), which is remarkable given the variation among other repeats. The papL-allele was only found in African P. hamadryas. Within this population, the allele frequency is lower than for the short allele (Table 1; papL: $25 \%$; papS: $75 \%$ ). All other screened baboon populations, including Arabian $P$. hamadryas, are monomorphic, carrying only the papS-allele. We, therefore, did not compare allele frequencies among species. Neither Prediction 1 (all baboon species carry the same alleles but in different frequencies) nor Prediction 2 (P. papio and P. ursinus are the most distinct species as concerns their genotypes) were confirmed for 5-HTTLPR.

Despite the considerable sequence variation among different repeats of the same allele, all Papionini exhibit a high similarity at the locus (Fig. 2; Additional file 2: Figure S1), confirming Prediction 3 (there are similar alleles in all papionin species). Differences in the core sequence (5'-CTGCACCCCTCCCAGCATCTCCC-3' compared to 5 '-CCCCCCCAGCATCCCCCCTGCA-3' in macaques; sequence from [22] with differences highlighted) are due to the method chosen to determine the repeat sequence (see Methods). Nevertheless, there are several length differences among taxa. The papL allele is the longest allele described so far in Papionini and has only been detected in African $P$. hamadryas. The other four non-Papio papionin species assessed in this study (Mandrillus sphinx, Mandrillus leucophaeus, Cercocebus chrysogaster, and Lophocebus aterrimus) carry an allele similar to the papS-allele and the allele described for Macaca sylvanus (msy-allele) [38].

5-HTTLPR in all other macaque species lacks a $23 \mathrm{bp}-$ repeat at PL2-3 (Fig. 2), resulting in shorter alleles. Macaca mulatta carries two alleles, one lacking only the repeat in PL2-3 $(r h L)$, and a shorter allele, which additionally lacks a repeat of $21 / 23$ bp at PL2-1 $(r h S)$ [21]. The $r h S$-allele has, so far, only been detected in $M$. mulatta, but several other macaque species carry an allele similar to $r h L[38,45]$ : crab-eating macaque $(M$. fascicularis; $m f a$ ), stump-tailed macaque (M. arctoides; not shown), Arunachal macaque (M. munzala; mmzL), bonnet macaque ( $M$. radiata; $m r a L)$, Tonkean macaque (M. tonkeana; not shown), pig-tailed macaque ( $M$. nemestrina; not shown), and lion-tailed macaque (M. silenus; msi). Macaca radiata and M. munzala carry an additional allele that lacks two repeats comprising $43 \mathrm{bp}$ at PL2-2 (mraS and $m m z S$ ). Finally, the only allele found in Tibetan macaque ( $M$. thibetana; $m t i)$ is similar to these two alleles. As sample sizes for M. thibetana and $M$. arctoides were small (three and two individuals, respectively) [38], it is possible that other alleles exist in these species. Taken together, papionin species differ at four sites within PL2; baboons vary only at one site (PL2-4), while macaques show considerable length variation and vary at three sites (PL2-1, PL2-2, and PL2-4).

\section{MAOALPR}

MAOALPR in baboons consists of a variable number of repeats with the core sequence $5^{\prime}$-ACYGGCACTGGCAYVACT-3'. Alleles with 8.8 (pap8), 9.8 (pap9), and 10.8 (pap10) repeats were detected (Fig. 3). In contrast to 5-HTTLPR, there is little variation in nucleotide composition among consecutive repeats (Fig. 3).

Confirming Prediction 1 (different baboon species carry the same alleles but in different frequencies) for MAOALPR, baboons show significant differences in allele frequencies among species (Cochran-Mantel-Haenszel test: $M_{8}^{2}=38.9184, \mathrm{P}<0.001$; Table 2, Fig. 1): Papio papio carries only the pap9-allele. Papio hamadryas carries mainly the pap9-allele $(84.4 \%)$ but some individuals also carry the pap8-allele (15.6\%). Papio anubis carries the pap8-allele and the pap9-allele in similar frequencies $(46.2 \%$ and $42.3 \%$, respectively), while the pap10-allele is less common (11.5\%). We observed considerable differences, however, among populations. West African P. anubis carries only the pap9-allele, while in East African P. anubis the pap8-allele is much more common $(75.0 \%)$ compared to the pap9-allele $(6.3 \%)$ or pap10-allele (18.8\%). Papio cynocephalus mainly carries the pap8-allele (52.9\%) and equal frequencies of the pap9-allele and the pap10-allele ( $23.5 \%$ each). Again, populations differ considerably; in northern P. cynocephalus the frequency of the pap8-allele is high $(72.7 \%)$ while the pap9-allele and the pap10-allele frequencies are 


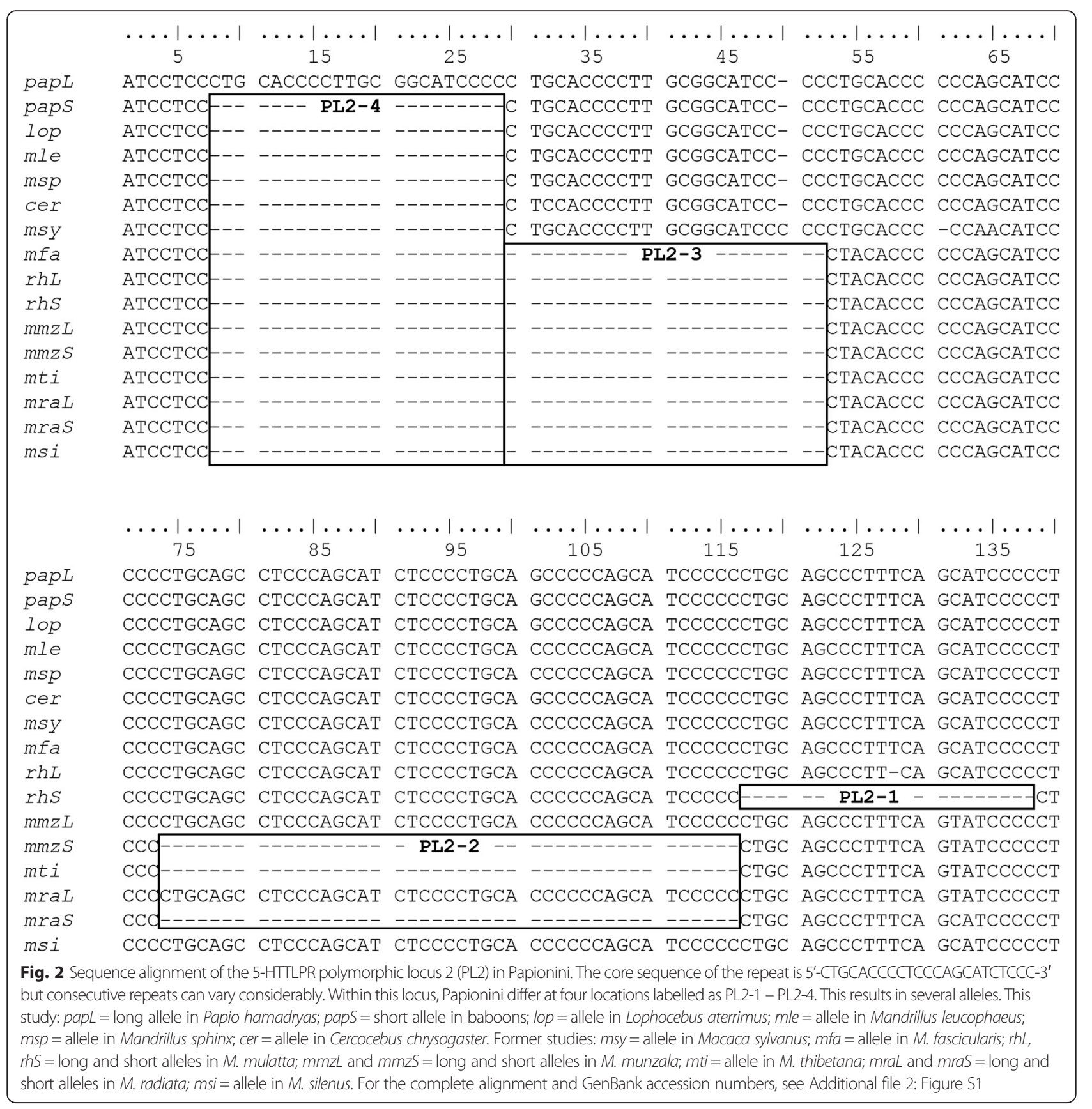

much lower (18.2\% and $9.1 \%$, respectively). In southern $P$. cynocephalus, the pap10-allele is the most common allele (50\%) and the other two alleles are less frequent (pap8: 16.7 \%; pap9: $33.3 \%$ ). Papio ursinus shows the highest frequency of the pap8-allele (65\%) and low frequency of the pap9-allele (35\%). As in P. anubis and P. cynocephalus, populations differ considerably; northern $P$. ursinus exclusively carries the shorter pap8-allele, while southern $P$. ursinus exclusively carries the pap9-allele.

Post-hoc tests (including populations as strata) indicate that $P$. papio differs significantly from $P$. anubis
$\left(M_{2}^{2}=17.74, p<0.001\right), P$. cynocephalus $\left(M_{2}^{2}=20.92, p<\right.$ $0.0001)$, and $P$. ursinus $\left(\chi_{1}^{2}=13.26, p<0.001\right.$; note that the test indicates $M_{2}^{2}$ for comparisons including three alleles, but $\chi_{1}^{2}$ if the compared populations only carry two alleles). Papio hamadryas differs significantly only from P. cynocephalus $\left(\mathrm{M}_{2}^{2}=16.42, p<0.001\right)$, while no significant differences were detected among $P$. anubis, $P$. cynocephalus and P. ursinus (all $p>0.09$ ). These results seem to confirm Prediction 2 ( $P$. papio and $P$. ursinus are the most distinct species as concerns their genotypes), but given the variation between both populations 
Table 1 Frequencies of 5-HTTLPR alleles in baboons (Papio spp.)

\begin{tabular}{|c|c|c|c|c|c|c|c|c|c|}
\hline \multirow[b]{3}{*}{ Species } & \multirow[b]{3}{*}{ Population } & & & & \multirow{3}{*}{$\begin{array}{l}\text { Total number } \\
\text { of alleles }\end{array}$} & \multicolumn{4}{|c|}{ Allele frequencies } \\
\hline & & \multicolumn{3}{|c|}{ Number of individuals } & & \multicolumn{2}{|c|}{ papl } & \multicolumn{2}{|c|}{ paps } \\
\hline & & $\bar{N}$ & Females & Males & & $\bar{N}$ & Freq. & $\bar{N}$ & Freq. \\
\hline \multirow{3}{*}{$\begin{array}{l}\text { Guinea baboons } \\
\text { (P. papio) }\end{array}$} & Total & 31 & 15 & 16 & 62 & & & 62 & $100.0 \%$ \\
\hline & West & 23 & 10 & 13 & 46 & & & 46 & $100.0 \%$ \\
\hline & East & 8 & 5 & 3 & 16 & & & 16 & $100.0 \%$ \\
\hline \multirow{3}{*}{$\begin{array}{l}\text { Hamadryas baboons } \\
\text { (P. hamadryas) }\end{array}$} & Total & 32 & 11 & 21 & 64 & 10 & $15.6 \%$ & 54 & $84.4 \%$ \\
\hline & African & 20 & 7 & 13 & 40 & 10 & $25.0 \%$ & 30 & $75.0 \%$ \\
\hline & Arabian & 12 & 4 & 8 & 24 & & & 24 & $100.0 \%$ \\
\hline \multirow{3}{*}{$\begin{array}{l}\text { Olive baboons } \\
\text { (P. anubis) }\end{array}$} & Total & 21 & 8 & 13 & 42 & & & 42 & $100.0 \%$ \\
\hline & West African & 11 & 2 & 9 & 22 & & & 22 & $100.0 \%$ \\
\hline & East African & 10 & 6 & 4 & 20 & & & 20 & $100.0 \%$ \\
\hline \multirow{3}{*}{$\begin{array}{l}\text { Yellow baboons } \\
\text { (P. cynocephalus) }\end{array}$} & Total & 21 & 8 & 13 & 42 & & & 42 & $100.0 \%$ \\
\hline & North & 9 & 4 & 5 & 18 & & & 18 & $100.0 \%$ \\
\hline & South & 12 & 4 & 8 & 24 & & & 24 & $100.0 \%$ \\
\hline \multirow{3}{*}{$\begin{array}{l}\text { Chacma baboons } \\
\text { (P. ursinus) }\end{array}$} & Total & 18 & 3 & 15 & 36 & & & 36 & $100.0 \%$ \\
\hline & South Africa & 5 & 2 & 3 & 10 & & & 10 & $100.0 \%$ \\
\hline & Moremi & 13 & 1 & 12 & 26 & & & 26 & $100.0 \%$ \\
\hline Total & & 123 & 45 & 78 & 246 & 10 & $4.1 \%$ & 236 & $95.9 \%$ \\
\hline
\end{tabular}

of $P$. ursinus, this result is difficult to interpret (see Discussion).

Compared with available data from other Papionini, the MAOALPR of baboons shows the same core sequence (Fig. 3). Notably, alleles of baboons are longer than those of other papionin species: macaques carry only five $(r h 5)$, six (rh6), or seven (rh7) repeats. Macaca mulatta carries all three of these alleles, M. fascicularis, M. nemestrina, and $M$. tonkeana carry the rh6-allelle and rh7-allele, $M$. thibetana and $M$. arctoides only the rh7-allele, and M. sylvanus only the rh6-allele [37]. Geladas (Theropithecus gelada), which are more closely related to baboons than to macaques (Fig. 4), carry alleles with six repeats, which is more similar to macaques. Therefore, Prediction 3 (there are similar alleles in all papionin species) is partly confirmed; the repeat sequence is highly similar but the number of repeats is higher in Papio species than in all other papionin species.

\section{Discussion}

In this study, we analyzed variation in 5-HTTLPR and MAOALPR genotypes in five species of baboons, which exhibit pronounced interspecific variation in aggressiveness. Almost no variation in 5-HTTLPR was detected. This indicates that the observed behavioral differences in baboons are not related to variation at this locus. Comparison with other papionin species indicates that this locus is much more variable among Asian macaques than among African Papionini. As discussed below, this may indicate differential selection pressure on 5-HTTLPR during or after the dispersal of macaques into Asia (though genetic drift may have also played a role). In contrast, there is large variation in the distribution of MAOALPR alleles in baboons. In some cases, however, intraspecific variation is as large as interspecific variation. Comparable behavioral data at the population level are required to resolve the role of MAOALPR alleles in behavioral differences among baboon populations and species.

\section{5-HTTLPR}

Four of the five baboon species are monomorphic in 5HTTLPR. Only some African (but no Arabian) P. hamadryas carry a second allele. Accordingly, the genotype of this locus cannot be associated with interspecific behavioral variation. As expected, however, all investigated papionin species show variation within the same area of this polymorphism, more specifically at PL2. In comparison with previous studies, these results give some insights into evolutionary changes in 5-HTTLPR in Papionini. Given the existence and supposed functionality of 5HTTLPR in many primates, such comparisons may help to better understand the evolution of promoter regions.

Wendland et al. [38] suggest that the msy-allele in $M$. sylvanus represents the ancestral allele in macaques. The present study confirms this assumption. Comparing alleles of 19 papionin species with respect to the evolutionary history of this tribe [71, 83, 84], suggests that the $m s y$-/papS-allele represents the ancestral state of the 


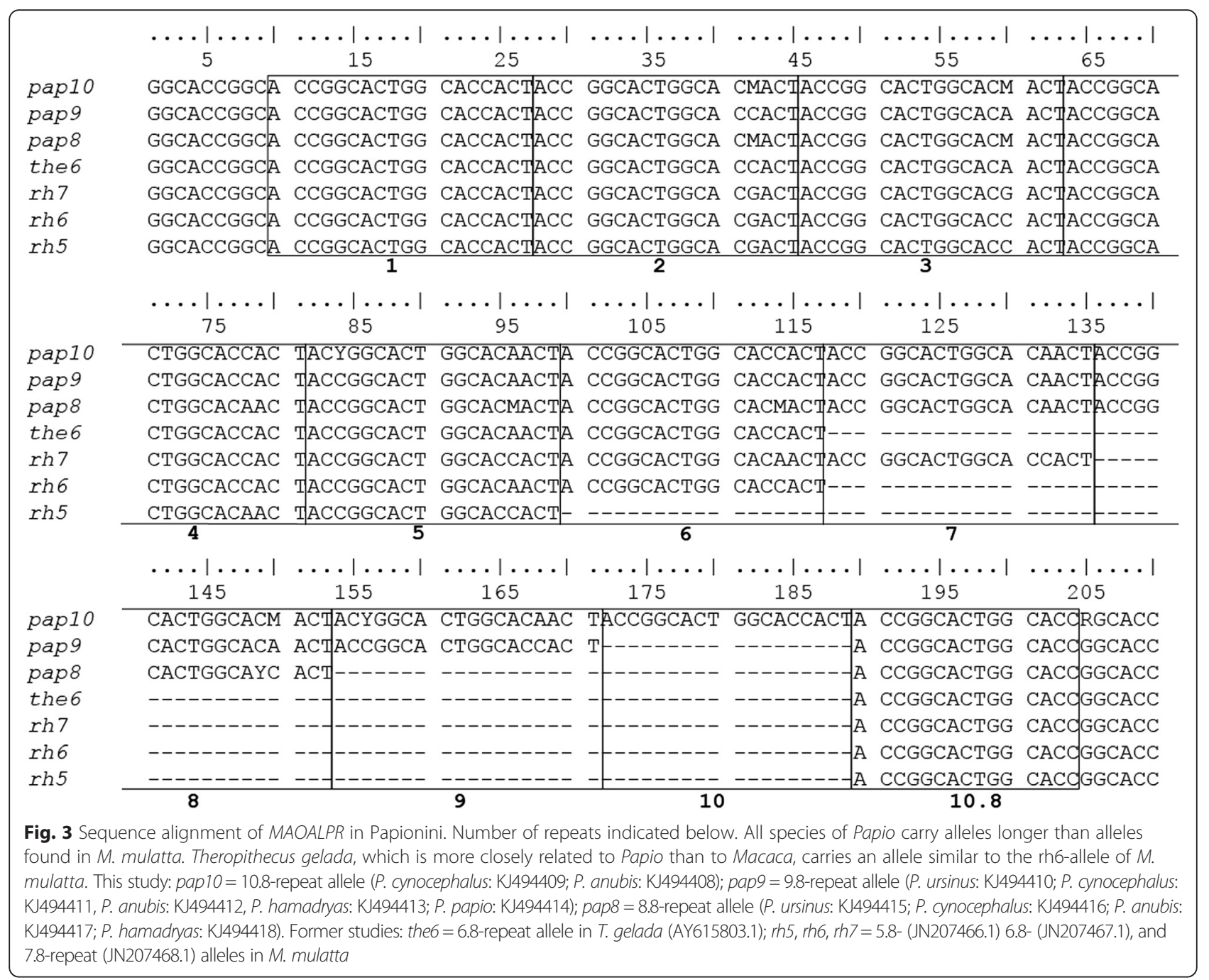

locus for all Papionini. To date, this is the most parsimonious explanation as it only assumes four changes during the last 8 million years (Fig. 4):

(1) As mentioned above, sequences of tandem repeats in this region are highly variable but the additional repeat at PL2-4 in the longest allele in Papionini, papL, is identical in sequence to the adjacent repeat (Additional file 2: Figure S1). This points towards a recent insertion of the PL2-4 repeat (Fig. 4, in red). Thus, the papL-allele probably emerged recently in some African P. hamadryas.

(2)After the split of $M$. sylvanus, other macaque species lost the repeat at PL2-3 (Fig. 4, in green), resulting in the $r h L$-allele. Interestingly, the other macaque species all occur in Asia, while M. sylvanus and all other Papionini (with the exception of some $P$. hamadryas in Arabia) live in Africa where the tribe is thought to have its origin [50]. Thus, Asian macaques probably lost the repeat at PL2-3 during their dispersal into Asia.

(3) The $r h S$-allele only occurs in M. mulatta. Thus, the partial loss of the repeat at PL2-1 (Fig. 4, in yellow) probably occurred after the split from other macaque species.

(4) Finally, mti-like alleles only occur in M. munzala, $M$. thibetana, and $M$. radiata, all of which belong to the Macaca sinica group [50, 85]. Thus, the deletion of two repeats at the PL2-2 (Fig. 4, in blue) probably occurred in the common ancestor of these three species.

Overall, this could indicate that selective pressures acting on this locus differ between Asian and African papionin populations. Interestingly, the short allele in humans (which differs at PL1) seems to be the derived version of the long human allele [86], and accordingly in humans, too, the long allele seems to be the ancestral 
Table 2 Frequencies of MAOALPR alleles in baboons (Papio spp.)

\begin{tabular}{|c|c|c|c|c|c|c|c|c|c|c|c|}
\hline \multirow[b]{3}{*}{ Species } & \multirow[b]{3}{*}{ Population } & & & & \multirow{3}{*}{$\begin{array}{l}\text { Total number } \\
\text { of alleles }{ }^{a}\end{array}$} & \multicolumn{6}{|c|}{ Allele frequencies } \\
\hline & & \multicolumn{3}{|c|}{ Number of individuals } & & \multicolumn{2}{|c|}{ pap8 } & \multicolumn{2}{|c|}{ pap9 } & \multicolumn{2}{|c|}{ pap10 } \\
\hline & & $\mathrm{N}$ & Females & Males & & $\mathrm{N}$ & Freq. & $\bar{N}$ & Freq. & $\bar{N}$ & Freq. \\
\hline \multirow{3}{*}{$\begin{array}{l}\text { Guinea baboons } \\
\text { (P. papio) }\end{array}$} & Total & 26 & 13 & 13 & 39 & & & 39 & $100.0 \%$ & & \\
\hline & West & 19 & 9 & 10 & 28 & & & 28 & $100.0 \%$ & & \\
\hline & East & 7 & 4 & 3 & 11 & & & 11 & $100.0 \%$ & & \\
\hline \multirow{3}{*}{$\begin{array}{l}\text { Hamadryas baboons } \\
\text { (P. hamadryas) }\end{array}$} & Total & 24 & 8 & 16 & 32 & 5 & $15.6 \%$ & 27 & $84.4 \%$ & & \\
\hline & African & 12 & 4 & 8 & 16 & 5 & $31.3 \%$ & 11 & $68.8 \%$ & & \\
\hline & Arabian & 12 & 4 & 8 & 16 & & & 16 & $100.0 \%$ & & \\
\hline \multirow{3}{*}{$\begin{array}{l}\text { Olive baboons } \\
\text { (P. anubis) }\end{array}$} & Total & 18 & 8 & 10 & 26 & 12 & $46.2 \%$ & 11 & $42.3 \%$ & 3 & $11.5 \%$ \\
\hline & West African & 8 & 2 & 6 & 10 & & & 10 & $100.0 \%$ & & \\
\hline & East African & 10 & 6 & 4 & 16 & 12 & $75.0 \%$ & 1 & $6.3 \%$ & 3 & $18.8 \%$ \\
\hline \multirow{3}{*}{$\begin{array}{l}\text { Yellow baboons } \\
\text { (P. cynocephalus) }\end{array}$} & Total & 13 & 4 & 9 & 17 & 9 & $52.9 \%$ & 4 & $23.5 \%$ & 4 & $23.5 \%$ \\
\hline & North & 8 & 3 & 5 & 11 & 8 & 72.7 \% & 2 & $18.2 \%$ & 1 & $9.1 \%$ \\
\hline & South & 5 & 1 & 4 & 6 & 1 & 16.7 \% & 2 & $33.3 \%$ & 3 & $50.0 \%$ \\
\hline \multirow{3}{*}{$\begin{array}{l}\text { Chacma baboons } \\
\text { (P. ursinus) }\end{array}$} & Total & 17 & 3 & 14 & 20 & 13 & $65.0 \%$ & 7 & $35.0 \%$ & & \\
\hline & South Africa & 5 & 2 & 3 & 7 & & & 7 & $100.0 \%$ & & \\
\hline & Moremi & 12 & 1 & 11 & 13 & 13 & $100.0 \%$ & & & & \\
\hline Total & & 98 & 36 & 62 & 134 & 39 & $29.1 \%$ & 88 & $65.7 \%$ & 7 & $5.2 \%$ \\
\hline
\end{tabular}

${ }^{\mathrm{a}} \mathrm{MAOA}$ is located on the $\mathrm{X}$-chromosome

version of the polymorphism. Furthermore, frequencies of the short allele vary among human populations. This variation cannot be solely explained by demographic factors; rather, selective pressures need to be considered [86]. The geographical allele distribution in humans [87], hereby, superficially resembles the distribution in papionin species; shorter alleles have a lower frequency in African ( 15-30 \%) than in Asian populations ( 70-80 \%), while European populations show intermediate frequencies ( 40-50\%). Whether the short allele confers an advantage requires further investigations [88]. In macaques, having several alleles in this genotype has been suggested to be beneficial in highly variable habitats $[44,45]$ (for an alternative hypothesis considering variation in social competition levels instead of variation in habitat, see [89]). To our knowledge, however, this hypothesis on the advantage of polymorphic populations in highly variable habitats has not been properly tested and comparisons of the variability of ecological conditions in Asian and African papionin habitats are not available. How range expansions by papionin species (also by humans and apes; see [90]) into new, ecologically highly variable, habitats relate to specific selective pressures and evolutionary dynamics may be a fruitful avenue for research.

Alternatively, the distribution of 5-HTTLPR alleles could be a result of random processes (i.e. genetic drift). Testing for selection signals, as commonly done in coding regions, is unfortunately much more complicated in promoter regions [19]. Due to the (nearly) universal genetic code, synonymous and non-synonymous mutations in coding regions are easily inferred from the sequence, while comparative information on promoter properties (e.g. transcription factor binding sites) must be assessed experimentally.

\section{MAOALPR}

$M A O A L P R$ allele frequencies differ significantly among some of the species, particularly between $P$. papio, which only carries the pap9-allele, and $P$. ursinus, $P$. cynocephalus, and $P$. anubis, which all show high frequencies of the pap8-allele. Inter-specific differences are, however, largely dependent on the inclusion (or exclusion) of specific populations because some of them show considerable intraspecific variation.

If populations are considered separately, do MAOALPR allele frequencies change gradually from south to north, and does this pattern fit with what we know about variation in aggressiveness in baboons? Generally, it appears that frequencies of the pap8-allele decrease and frequencies of the pap9-allele increase from southern populations ( $P$. ursinus in Moremi) to north-western (all P. papio) and northeastern populations (all $P$. hamadryas). While P. papio and P. hamadryas show some similarities in their behavior (e.g. male bonds, male-male greetings, and strong intersexual bonds), $P$. ursinus from Moremi differed fundamentally from $P$. papio from Senegal in male aggressiveness and 


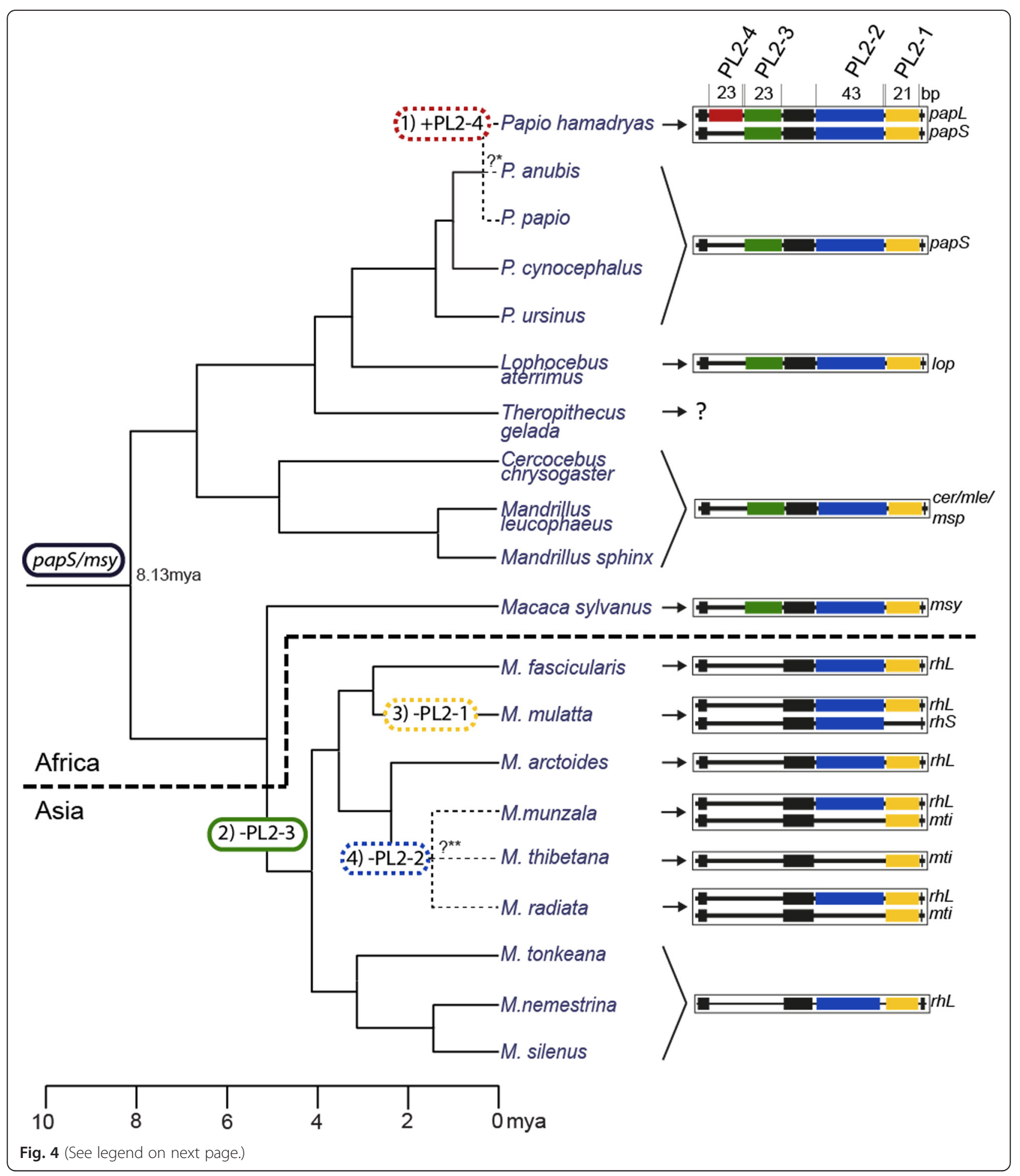


(See figure on previous page.)

Fig. 4 Distribution and presumed evolutionary history of alleles in 5-HTTLPR in Papionini. Shown are hypothesized positions of insertions/deletions (indels) of repeats within the polymorphic locus 2 (PL2) in the phylogenetic tree for Papionini. Partial indels are encircled by dashed lines and complete indels by solid lines. The results of this study indicate that an allele similar to $m s y$ and papS/lop/cer/m/e/msp represents the ancestral state of the locus for all Papionini, and that the following four changes occurred during the last 8 million years (for details see Discussion): (1) The additional repeat at PL2-4 (red) in the papL-allele represents an insertion that only emerged recently in some African P. hamadryas. (2) After the split of M. sylvanus, the ancestor of all other species of Macaca lost the repeat at PL2-3 (green), probably during or after their dispersal to Asia. (3) The partial loss of the repeat at PL2-1 (yellow) occurred in M. mulatta after the split from other macaque species. (4) The deletion of two repeats at the PL2-2 (blue) occurred in the common ancestor of the M. sinica-group of macaques, which includes M. munzala, M. thibetana, and M. radiata. Phylogenetic tree and divergence ages adapted from [71], and modified for Papio from [83]. *The phylogenetic relationship between P. anubis, P. hamadryas and P. papio is still debated [83]. ${ }^{* *}$ Comparable data for M. munzala and $M$. radiata are lacking but both species belong, together with M. thibetana, to the M. sinica-group of macaques [85]

tolerance [5]. In accordance with the gradual change in allele frequencies, East African $P$. anubis mainly carries the pap8-allele while West African P. anubis, which lives geographically closer to $P$. papio, only carries the pap9-allele. These two populations of $P$. anubis show differences in their social organization [91], but it is not known whether the western population is more similar in aggressiveness to P. papio than to the eastern population.

Two populations do not conform to the gradual change in allele frequencies. First, southern $P$. cynocephalus mainly carries the pap10-allele, which is only found in the two P. cynocephalus populations and in East African P. anubis. Second, South Africa P. ursinus carries only the pap9-allele. As such, it is similar in its $M A O A L P R$ genotype to $P$. papio, but like its conspecifics from Moremi, South Africa P. ursinus shows several indications of intense male contest competition [92-94]. Nevertheless, directly comparable data on aggressiveness are not yet available and, accordingly, it is not possible, at this time, to link the MAOALPR genotype to variation in aggressiveness among baboon populations.

Another important question is the functionality of the MAOALPR in baboons. Studies on humans [35], apes [90,95], and macaques [36] indicate that variation at the MAOALPR genotype has an effect on transcriptional activity. Corresponding gene expression studies for baboons are still lacking but such studies are required in order to understand the role of this polymorphism in baboon behavior. Importantly, MAOA is involved in other monoamine neurotransmitter systems in addition to 5$\mathrm{HT}$, while $5-\mathrm{HT}$ transporter activity only affects the $5-\mathrm{HT}$ system. For example, MAOA also metabolizes noradrenalin (NA) and dopamine (DA), and both of these monoamines appear to play an important role in the expression of aggression (reviews in [13, 96-98]).

Despite these limitations, it appears that comparative data on monoamine neurotransmitter levels from different baboon populations would be informative with respect to the link between differential MAOA activity and behavior. So far, such data are only available for some $P$. hamadryas and $P$. anubis from Ethiopia $[99,100]$. The authors measured cerebrospinal fluid (CSF) levels of 5-HIAA (the metabolite of 5-HT), homovanillic acid (HVA; the metabolite of DA), and 3-methoxy-4-hydroxyphenylglycol (MHPG; the metabolite of NA). While they could not detect a significant difference in 5-HIAA levels, adult male $P$. hamadryas showed higher levels of HVA and MHPG than adult male $P$. anubis. Therefore, behavioral variation in baboons could be associated with differential activity of monoamine neurotransmitters other than 5-HT, potentially regulated by differences in MAOA availability as a result of a given MAOALPR genotype.

\section{Conclusion}

The results of this study suggest that there is no corresponding variation in behavior and 5-HTTLPR in baboons. Nevertheless, comparisons of alleles among 19 papionin species indicate differences among African and Asian species that are potentially linked to geographic differences in selective pressures on this locus. MAOALPR, on the other hand, shows considerable interspecific and intraspecific variation in allele frequencies. Therefore, further information on behavioral variation at the population level is needed to investigate whether the genotype of this so-called 'warrior gene' may play a role in behavioral variation in baboons. In addition to comparisons at the population level, future studies should investigate the effect of different alleles on transcription profiles, protein levels, neurotransmitter levels, and individual behavior within polymorphic populations of baboons. While this explorative study represents one of the first steps to investigate the genetics underlying variation in aggressiveness among baboon species and populations, future studies should examine sequence variation in coding and non-coding regions of those genes encoding for other proteins involved in neurotransmitter systems.

\section{Additional files}

Additional file 1: Table S1. Sample locations and genotypes. (PDF $37 \mathrm{~kb}$ )

Additional file 2: Figure S1. Complete alignment of 5-HTTLPR in Papionini. Sequences from this study (with GenBank-Accession numbers): $p a p S(P U)=$ short allele in $P$. ursinus (KJ494398); $p a p S(P C)=$ short allele in $P$. cynocephalus (KJ494399); papS(PA) = short allele in $P$. anubis (KJ494400); papS(PH) = short allele in P. hamadryas (KJ494401); papL $(P H)=$ long allele in $P$. hamadryas (KJ494402); papS(PP) = short 
allele in P. papio (KJ494403); lop = allele from Lophocebus aterrimus (KJ494404); mle = allele from Mandrillus leucophaeus (KJ494405); msp = allele from Mandrillus sphinx (KJ494406); cer = allele from Cercocebus chrysogaster (KJ494407). Sequences described for Macaca spp. originating from other studies: $m s y=$ allele $M$. sylvanus (AY897212.1); $m f a=$ allele in M. fascicularis (EF126284.1); $r$ LL, $r h S=$ long (AF191557.1) and short (Lesch et al. 1997; Wendland et al. 2006) alleles in M. mulatta; $m m z L$ and $m m z S=$ long (HM114278.1) and short (HM114279.1) alleles in M. munzala; $m$ ti $=$ allele in $M$. thibetana (AY897213.1); $\mathrm{mraL}$ and $\mathrm{mraS}=$ long (HM114280.1) and short (HM114281.1) alleles in M. radiata; $m s i=$ allele in $M$. silenus (HM114282.1). (RTF $919 \mathrm{~kb}$ )

\section{Acknowledgements}

The study was supported by the Leibniz Graduate School 'Foundations of Primate Behaviour'. We thank Annika Patzelt, Peter Maciej, Christina Keller, Elodie Ey, Ulrike Barnett, and the zoological gardens of Gettorf, Wuppertal, and Rostock, for providing samples. We especially want to thank all local assistants and national wildlife authorities for providing researchers on former studies with permission to collect and export samples. We thank the Diréction des Parcs Nationaux and Ministère de l'Environnement et de la Protéction de la Nature, Sénégal, for long-term support and for permission to work in Niokolo Koba National Park. Samples from Lake Manyara National Park, Tanzania, were taken with permission of TAWIRI and TANAPA (TNP/HQ/ E.20/08B) as well as COSTECH (2007-56-NA-2006-176), which are also thanked for long-term support of baboon research. We thank Christiane Schwarz for technical help; Dorothy Cheney and Robert Seyfarth for scientific discussions and support in Botswana; and Christopher Foote, Lorna Depew, and two anonymous referees for their invaluable comments. UK thanks Jan Kalbitzer for inspiring discussions.

\section{Availability of supporting data}

DNA sequences are available at GenBank, accession numbers: KJ494398-KJ494418.

\section{Authors' contributions}

Conception and design of the study: UK, CR, JF. Genetic data collection: UK, CR, GHK, TMB, SK, DZ. Data analysis: UK, CR. Manuscript drafting: UK, JF. All authors contributed to the finalization of the manuscript and approved the final version.

\section{Competing interests}

The authors declare that they have no competing interests.

\section{Author details}

${ }^{1}$ Cognitive Ethology Laboratory, German Primate Center (DPZ), Leibniz Institute for Primate Research, Kellnerweg 4, 37077 Göttingen, Germany. ${ }^{2}$ Department of Anthropology and Archaeology, University of Calgary, 2500 University Dr NW, Calgary, AB T2N 1N4, Canada. ${ }^{3}$ Gene Bank of Primates and Primate Genetics Laboratory, German Primate Center (DPZ), Leibniz Institute for Primate Research, Kellnerweg 4, 37077 Göttingen, Germany. ${ }^{4}$ Department of Biology, University of Konstanz, 78457 Constance, Germany. ${ }^{5}$ Department of Migration and Immuno-Ecology, Max Planck Institute for Ornithology, Am Obstberg 1, 78315 Radolfzell, Germany. ${ }^{6}$ Lolldaiga Hills Research Programme, Sustainability Centre Eastern Africa, P. O. Box 149, Nanyuki 10400, Kenya. 'Work Group Neglected Tropical Diseases, Pathology Unit, German Primate Center (DPZ), Leibniz Institute for Primate Research, Kellnerweg 4, 37077 Göttingen, Germany.

Received: 13 February 2016 Accepted: 25 May 2016

Published online: 10 June 2016

\section{References}

1. Zinner $\mathrm{D}$, Wheeler $\mathrm{BC}$. Violence among our closest relatives - aggression in nonhuman primate societies. In: Kortuem H-H, Heinze J, editors. Aggress. Hum. Primates Biol. Psychol. Sociol. Berlin/Boston: Walter de Gruyter; 2012. p. 41-85.

2. Anholt RRH, Mackay TFC. Genetics of aggression. Annu Rev Genet. 2012;46: 145-64.

3. Yeh MT, Coccaro EF, Jacobson KC. Multivariate behavior genetic analyses of aggressive behavior subtypes. Behav Genet. 2010;40:603-17.
4. Bester-Meredith JK, Young $\sqcup$, Marler CA. Species differences in paternal behavior and aggression in Peromyscus and their associations with vasopressin immunoreactivity and receptors. Horm Behav. 1999;36:25-38.

5. Kalbitzer U, Heistermann M, Cheney D, Seyfarth R, Fischer J. Social behavior and patterns of testosterone and glucocorticoid levels differ between male chacma and Guinea baboons. Horm Behav. 2015;75:100-10.

6. Thierry B. Covariation of conflict management patterns across macaque species. In: Aureli F, Waal FBM, editors. Nat. Confl. Resolut. Berkeley, Los Angeles, London: University of California Press; 2000. p. 106-28.

7. Fairbanks LA, Newman TK, Bailey JN, Jorgensen MJ, Breidenthal SE, Ophoff RA, et al. Genetic contributions to social impulsivity and aggressiveness in vervet monkeys. Biol Psychiatry. 2004;55:642-7.

8. Van Oortmerssen GA, Bakker TCM. Artificial selection for short and long attack latencies in wild Mus musculus domesticus. Behav Genet. 1981;11:115-26.

9. Belyaev DK. Destabilizing selection as a factor in domestication. J Hered. 1979;70:301-8.

10. Craig IW, Halton KE. Genetics of human aggressive behaviour. Hum Genet. 2009;126:101-13.

11. Popova NK. From genes to aggressive behavior: the role of serotonergic system. Bioessays. 2006;28:495-503.

12. Nelson RJ, Chiavegatto S. Molecular basis of aggression. Trends Neurosci. 2001;24:713-9.

13. Yanowitch $R$, Coccaro EF. The neurochemistry of human aggression. In: Huber R, Bannasch DL, Brennan P, editors. Aggression. San Diego, USA: Academic; 2011. p. 151-69.

14. Clarke SA, Kammerer CM, George KP, Kupfer DJ, McKinney WT, Anne Spence $\mathrm{M}$, et al. Evidence for heritability of biogenic amine levels in the cerebrospinal fluid of rhesus monkeys. Biol Psychiatry. 1995;38:572-7.

15. Rogers J, Martin LJ, Comuzzie AG, Mann JJ, Manuck SB, Leland M, et al. Genetics of monoamine metabolites in baboons: overlapping sets of genes influence levels of 5-hydroxyindolacetic acid, 3-hydroxy-4methoxyphenylglycol, and homovanillic acid. Biol Psychiatry. 2004;55:739-44.

16. Higley JD, Mehlman PT, Taub DM, Higley SB, Suomi SJ, Linnoila M, et al. Cerebrospinal fluid monoamine and adrenal correlates of aggression in free-ranging rhesus monkeys. Arch Gen Psychiatry. 1992;49:436-41.

17. Howell S, Westergaard G, Hoos B, Chavanne TJ, Shoaf SE, Cleveland A, et al. Serotonergic influences on life-history outcomes in free-ranging male rhesus macaques. Am J Primatol. 2007;69:851-65.

18. Higley JD, King Jr ST, Hasert MF, Champoux M, Suomi SJ, Linnoila M. Stability of interindividual differences in serotonin function and its relationship to severe aggression and competent social behavior in rhesus macaque females. Neuropsychopharmacology. 1996;14:67-76.

19. Wray GA. The evolution of transcriptional regulation in eukaryotes. Mol Biol Evol. 2003;20:1377-419.

20. Heils A, Teufel A, Petri S, Stoeber G, Riederer P, Bengel D. Allelic variation of human serotonin transporter gene expression. J Neurochem. 1996;66:2621-4.

21. Lesch KP, Meyer J, Glatz K, Fluegge G, Hinney A, Hebebrand J, et al. The 5HT transporter gene-linked polymorphic region (5-HTTLPR) in evolutionary perspective: alternative biallelic variation in rhesus monkeys. J Neural Transm. 1997;104:1259-66.

22. Trefilov A, Berard J, Krawczak M, Schmidtke J. Natal dispersal in rhesus macaques is related to serotonin transporter gene promoter variation. Behav Genet. 2000:30:295-301.

23. Inoue-Murayama M, Niimi Y, Takenaka O, Okada K, Matsuzaki I, Ito S'ichi, et al. Allelic variation of the serotonin transporter gene polymorphic region in apes. Primates. 2000;41:267-73.

24. Bennett AJ, Lesch KP, Heils A, Long JC, Lorenz JG, Shoaf SE, et al. Early experience and serotonin transporter gene variation interact to influence primate CNS function. Mol Psychiatry. 2002;7:118-22.

25. Lesch KP, Bengel D, Heils A, Sabol SZ, Greenberg BD, Petri S, et al. Association of anxiety-related traits with a polymorphism in the serotonin transporter gene regulatory region. Science. 1996;274:1527-31.

26. Canli T, Lesch K-P. Long story short: the serotonin transporter in emotion regulation and social cognition. Nat Neurosci. 2007;10:1103-9.

27. Barr CS, Newman TK, Becker ML, Parker CC, Champoux M, Lesch KP, et al. The utility of the non-human primate model for studying gene by environment interactions in behavioral research. Genes Brain Behav. 2003; 2:336-40.

28. Schwandt ML, Lindell SG, Sjöberg RL, Chisholm KL, Higley JD, Suomi SJ, et al. Gene-environment interactions and response to social intrusion in male and female rhesus macaques. Biol Psychiatry. 2010;67:323-30. 
29. Ficks CA, Waldman ID. Candidate genes for aggression and antisocial behavior: A meta-analysis of association studies of the 5HTTLPR and MAOAUVNTR. Behav Genet. 2014;44:427-44.

30. Vassos E, Collier DA, Fazel S. Systematic meta-analyses and field synopsis of genetic association studies of violence and aggression. Mol Psychiatry. 2014; 19:471-7.

31. Brunner HG, Nelen M, Breakefield XO, Ropers HH, van Oost BA. Abnormal behavior associated with a point mutation in the structural gene for monoamine oxidase A. Science. 1993;262:578-80.

32. Cases O, Seif I, Grimsby J, Gaspar P, Chen K, Pournin S, et al. Aggressive behavior and altered amounts of brain serotonin and norepinephrine in mice lacking MAOA. Science. 1995;268:1763-6.

33. Popova NK, Skrinskaya YA, Amstislavskaya TG, Vishnivetskaya GB, Seif I, de Meier E. Behavioral characteristics of mice with genetic knockout of monoamine oxidase type A. Neurosci Behav Physiol. 2001:31:597-602.

34. Scott AL, Bortolato M, Chen K, Shih JC. Novel monoamine oxidase A knock out mice with human-like spontaneous mutation. Neuroreport. 2008;19:739-43.

35. Sabol SZ, Hu S, Hamer D. A functional polymorphism in the monoamine oxidase A gene promoter. Hum Genet. 1998;103:273-9.

36. Newman TK, Syagailo YV, Barr CS, Wendland JR, Champoux M, Graessle M, et al. Monoamine oxidase A gene promoter variation and rearing experience influences aggressive behavior in rhesus monkeys. Biol Psychiatry. 2005;57:167-72.

37. Wendland JR, Hampe M, Newman TK, Syagailo Y, Meyer J, Schempp W, et al. Structural variation of the monoamine oxidase A gene promoter repeat polymorphism in nonhuman primates. Genes Brain Behav. 2006;5:40-5.

38. Wendland JR, Lesch KP, Newman TK, Timme A, Gachot-Neveu H, Thierry B, et al. Differential functional variability of serotonin transporter and monoamine oxidase a genes in macaque species displaying contrasting levels of aggression-related behavior. Behav Genet. 2006;36:163-72.

39. Inoue-Murayama M, Mishima N, Hayasaka I, Ito S, Murayama Y. Divergence of ape and human monoamine oxidase A gene promoters: Comparative analysis of polymorphisms, tandem repeat structures and transcriptional activities on reporter gene expression. Neurosci Lett. 2006;405:207-11.

40. Caspi A. Role of genotype in the cycle of violence in maltreated children. Science. 2002:297:851-4

41. Karere GM, Kinnally EL, Sanchez JN, Famula TR, Lyons LA, Capitanio JP. What is an "adverse" environment? Interactions of rearing experiences and MAOA genotype in rhesus monkeys. Biol Psychiatry. 2009;65:770-7.

42. Manuck SB, Flory JD, Ferrell RE, Mann JJ, Muldoon MF. A regulatory polymorphism of the monoamine oxidase-A gene may be associated with variability in aggression, impulsivity, and central nervous system serotonergic responsivity. Psychiatry Res. 2000;95:9-23.

43. McDermott R, Tingley D, Cowden J, Frazzetto G, Johnson DD. Monoamine oxidase A gene (MAOA) predicts behavioral aggression following provocation. Proc Natl Acad Sci. 2009;106:2118-23.

44. Suomi SJ. Risk, resilience, and gene $x$ environment interactions in rhesus monkeys. Ann N Y Acad Sci. 2006;1094:52-62.

45. Chakraborty S, Chakraborty D, Mukherjee O, Jain S, Ramakrishnan U, Sinha A Genetic polymorphism in the serotonin transporter promoter region and ecological success in macaques. Behav Genet. 2010:40:672-9.

46. Zinner D, Wertheimer J, Liedigk R, Groeneveld LF, Roos C. Baboon phylogeny as inferred from complete mitochondrial genomes. Am J Phys Anthropol. 2013;150:133-40.

47. Anandam MV, Bennett EL, Davenport TRB, Davies NJ, Detwiler KM Engelhardt A, et al. Species accounts of Cercopithecidae. Handb. Mamm. World. Barcelona: Lynx Edicions; 2013. p. 628-753.

48. Butynski TM, Kingdon J, Kalina J, editors. Mammals of Africa. London: Bloomsbury; 2013.

49. Groves CP. Primate Taxonomy. Washington DC: Smithsonian Institution Press; 2001.

50. Zinner D, Fickenscher GH, Roos C. Family Cercopithecidae (Old World Monkeys). In: Mittermeier RA, Rylands AB, Wilson EW, editors. Handb. Mamm. World - Vol 3 Primates. Barcelona: Lynx Edicions; 2013. p. 550-627.

51. Henzi P, Barrett L. Evolutionary ecology, sexual conflict, and behavioral differentiation among baboon populations. Evol Anthropol. 2003;12:217-30.

52. Jolly CJ. Fifty years of looking at human evolution. Curr Anthropol. 2009;50: 187-99.

53. Alberts SC, Watts HE, Altmann J. Queuing and queue-jumping: long-term patterns of reproductive skew in male savannah baboons. Papio cynocephalus Anim Behav. 2003;65:821-40.
54. Bulger JB. Dominance rank and access to estrous females in male savanna baboons. Behaviour. 1993;127:67-103.

55. Packer C. Male dominance and reproductive activity in Papio anubis. Anim Behav. 1979;27(Part 2):37-45.

56. Drews $\mathrm{C}$. Contexts and patterns of injuries in free-ranging male baboons (Papio cynocephalus). Behaviour. 1996:133:443-74.

57. Kitchen D, Cheney D, Seyfarth R. Contextual factors meditating contests between male chacma baboons in Botswana: effects of food, friends and females. Int J Primatol. 2005;26:105-25.

58. MacCormick HA, MacNulty DR, Bosacker AL, Lehman C, Bailey A, Anthony Collins D, et al. Male and female aggression: lessons from sex, rank, age, and injury in olive baboons. Behav Ecol. 2012;23:684-91.

59. Smuts BB. Sex and Friendship in Baboons. New York: Aldine; 1985.

60. Noe R, Sluijter AA. Reproductive tactics of male savanna baboons Behaviour. 1990;113:117-69.

61. Kummer H. Social Organization of Hamadryas Baboons: A Field Study. Chicago: University of Chicago Press; 1968.

62. Swedell L. Hamadryas social organization: the haves and the have-nots. Strateg. Sex Surviv. Hamadryas Baboons Female Lens. New Jersey: Pearson Prentice Hall; 2006.

63. Galat-Luong A, Galat G, Hagell S. The social and ecological flexibility of Guinea baboons: Implications for Guinea baboon social organization and male strategies. In: Swedell L, Leigh SR, editors. Reprod. Fit. Baboons Behav. Ecol. Life Hist. Perspect. New York: Springer; 2006. p. 105-21.

64. Patzelt A, Kopp GH, Ndao I, Kalbitzer U, Zinner D, Fischer J. Male tolerance and male-male bonds in a multilevel primate society. Proc Natl Acad Sci. 2014;111:14740-5.

65. Sharman MJ. Feeding, ranging and social organisation of the Guinea baboon. St. Andrews, UK: University of St. Andrews; 1981

66. Barton RA, Whiten A. Feeding competition among female olive baboons. Papio anubis Anim Behav. 1993:46:777-89.

67. Packer C, Collins DA, Sindimwo A, Goodall J. Reproductive constraints on aggressive competition in female baboons. Nature. 1995;373:60-3.

68. Silk JB, Alberts SC, Altmann J. Patterns of coalition formation by adult female baboons in Amboseli. Kenya Anim Behav. 2004;67:573-82.

69. Swedell L. Affiliation among females in wild hamadryas baboons (Papio hamadryas hamadryas). Int J Primatol. 2002;23:1205-26.

70. Goffe AS, Zinner D. Fischer J. Sex and friendship in a multilevel society: behavioural patterns and associations between female and male Guinea baboons. Behav Ecol Sociobiol. 2016;70:323-36.

71. Perelman P, Johnson WE, Roos C, Seuánez HN, Horvath JE, Moreira MAM, et al. A molecular phylogeny of living primates. PLoS Genet. 2011;7, e1001342.

72. Knauf S, Batamuzi EK, Mlengeya T, Kilewo M, Lejora IAV, Nordhoff M, et al. Treponema infection associated with genital ulceration in wild baboons. Vet Pathol. 2011:49:292-303.

73. Kopp GH, Roos C, Butynski TM, Wildman DE, Alagaili AN, Groeneveld LF, et al. Out of Africa, but how and when? The case of hamadryas baboons (Papio hamadryas). J Hum Evol. 2014;76:154-64.

74. Kopp GH, da Silva MJ F, Fischer J, Brito JC, Regnaut S, Roos C, et al. The Influence of Social Systems on Patterns of Mitochondrial DNA Variation in Baboons. Int J Primatol. 2013:35:210-25.

75. Keller C, Roos C, Groeneveld LF, Fischer J, Zinner D. Introgressive hybridization in southern African baboons shapes patterns of mtDNA variation. Am J Phys Anthropol. 2010;142:125-36.

76. Jullien N. AmplifX [Internet]. France: CNRS, Aix-Marseille Université; 2013. Available from: http://crn2m.univ-mrs.fr/pub/amplifx-dist.

77. Buchan JC, Archie EA, Van Horn RC, Moss CJ, Alberts SC. Locus effects and sources of error in noninvasive genotyping. Mol Ecol Notes. 2005;5:680-3.

78. Perry GH, Marioni JC, Melsted P, Gilad Y. Genomic-scale capture and sequencing of endogenous DNA from feces: genomic-scale sequencing of fecal DNA. Mol Ecol. 2010;19:5332-44.

79. Hall TA. BioEdit: a user-friendly biological sequence alignment editor and analysis program for Windows 95/98/NT. Nucleic Acids Symp Ser. 1999;No. 41:95-8.

80. Benson G. Tandem repeats finder: a program to analyze DNA sequences. Nucleic Acids Res. 1999:27:573-80.

81. Miller CR, Joyce P, Waits LP. Assessing allelic dropout and genotype reliability using maximum likelihood. Genetics. 2002;160:357-66.

82. R Core Team. R. A Language and Environment for Statistical Computing [Internet]. Vienna, Austria: R Foundation for Statistical Computing: 2014. Available from: http://www.R-project.org/. Accessed 30 May 2016. 
83. Boissinot S, Alvarez L, Giraldo-Ramirez J, Tollis M. Neutral nuclear variation in baboons (genus Papio) provides insights into their evolutionary and demographic histories. Am J Phys Anthropol. 2014;155:621-34.

84. Guevara EE, Steiper ME. Molecular phylogenetic analysis of the Papionina using concatenation and species tree methods. J Hum Evol. 2014;66:18-28.

85. Chakraborty D, Ramakrishnan U, Panor J, Mishra C, Sinha A. Phylogenetic relationships and morphometric affinities of the Arunachal macaque Macaca munzala, a newly described primate from Arunachal Pradesh, northeastern India. Mol Phylogenet Evol. 2007;44:838-49.

86. Claw KG, Tito RY, Stone AC, Verrelli BC. Haplotype structure and divergence at human and chimpanzee serotonin transporter and receptor genes: implications for behavioral disorder association analyses. Mol Biol Evol. 2010; 27:1518-29.

87. Esau L, Kaur M, Adonis L, Arieff Z. The 5-HTTLPR polymorphism in South African healthy populations: a global comparison. J Neural Transm. 2008; 115:755-60.

88. Kalbitzer J, Kalbitzer U, Knudsen GM, Cumming P, Heinz A. How the cerebral serotonin homeostasis predicts environmental changes: a model to explain seasonal changes of brain 5-HTT as intermediate phenotype of the 5HTTLPR. Psychopharmacology (Berl). 2013;230:333-43.

89. Dobson SD, Brent LJN. On the evolution of the serotonin transporter linked polymorphic region (5-HTTLPR) in primates. Front Hum Neurosci. 2013;7:1-9.

90. Inoue-Murayama M. Genetic polymorphism as a background of animal behavior. Anim Sci J. 2009;80:113-20.

91. Kunz BK, Linsenmair KE. The disregarded West: Diet and behavioural ecology of olive baboons in the Ivory Coast. Folia Primatol. 2008;79:31-51.

92. Clarke PMR, Henzi SP, Barrett L, Rendall D. On the road again: competitive effects and condition-dependent dispersal in male baboons. Anim Behav. 2008;76:55-63.

93. Weingrill T, Lycett JE, Barrett L, Hill RA, Henzi SP. Male consortship behaviour in chacma baboons: the role of demographic factors and female conceptive probabilities. Behaviour. 2003;140:405-27.

94. Weingrill T, Lycett JE, Henzi SP. Consortship and mating success in chacma baboons (Papio cynocephalus ursinus). Ethology. 2000;106:1033-44.

95. Choi Y, Jung Y-D, Ayarpadikannan S, Koga A, Imai H, Hirai H, et al. Novel variable number of tandem repeats of gibbon MAOA gene and its evolutionary significance. Genome. 2014;57:427-32.

96. Miczek KA, Fish EW, de Bold JF, de Almeida RM. Social and neural determinants of aggressive behavior: pharmacotherapeutic targets at serotonin, dopamine and g-aminobutyric acid systems. Psychopharmacology (Berl). 2002;163:434-58.

97. Miczek KA, Fish EW. Dopamine, glutamate, and aggression. In: Schmidt WJ, Reith ME, editors. Dopamine Glutamate Psychiatr. Disord. Totowa, N.J: Humana Press; 2005. p. 237-63.

98. Nelson RJ, Trainor BC. Neural mechanisms of aggression. Nat Rev Neurosci. 2007;8:536-46.

99. Jolly C, Phillips-Conroy J, Kaplan J, Mann J. Cerebrospinal fluid monoaminergic metabolites in wild Papio anubis and $P$. hamadryas are concordant with taxon-specific behavioral ontogeny. Int. J. Primatol. 2008; 29:1549-66.

100. Jolly CJ, Phillips-Conroy JE, Kaplan JR, Mann JJ. Monoamine neurotransmitter metabolites in the cerebrospinal fluid of a group of hybrid baboons (Papio hamadryas X P. anubis). Int J Primatol. 2013;34:836-58.

\section{Submit your next manuscript to BioMed Central and we will help you at every step:}

- We accept pre-submission inquiries

- Our selector tool helps you to find the most relevant journal

- We provide round the clock customer support

- Convenient online submission

- Thorough peer review

- Inclusion in PubMed and all major indexing services

- Maximum visibility for your research

Submit your manuscript at www.biomedcentral.com/submit
Biomed Central 